\title{
Dividend Policy and Firm's Profitability: Evidence from Ethiopian Private Insurance Companies
}

\author{
Niway Ayalew Adimasu \\ Department of Accounting and Finance, College of Business and Economics, Debre Berhan University, Debre Berhan, Ethiopia \\ Email address: \\ neway5450@gmail.com \\ To cite this article: \\ Niway Ayalew Adimasu. Dividend Policy and Firm's Profitability: Evidence from Ethiopian Private Insurance Companies. Journal of \\ Finance and Accounting. Vol. 7, No. 4, 2019, pp. 116-121. doi: 10.11648/j.jfa.20190704.12
}

Received: July 16, 2019; Accepted: August 13, 2019; Published: August 26, 2019

\begin{abstract}
In many rapidly growing economies and emerging markets like Ethiopia, the insurance companies are expected to play a crucial role. The dividend decision is one of the critical financial managementdecisions for firms. Dividend decision is also among the widely addressed and controversial issue in field of finance. The inconclusiveness of dividend theories and empirical studies on the relationship between firm's profitability and dividend payout decisions is one of the most debatable topics inresearches. Hence, the objective of this study is to examine the relationship between dividend policy and Ethiopianprivate insurance company's profitability and to contribute to the ongoing debate. To achieve the objective of this study, secondary data were collected from the Audited annual financial statements of 8 private insurance companies in Ethiopia, from year 2006-2015. The study used purposive sampling technique to collect the necessary data. Descriptive statistics and Pearson correlation matrix were used for data analysis. Paneldata andPooled OLS regression model were also employed for empirical testing. Return on Asset (ROA) used as a measurement of insurance company's profitability (dependent variable) while dividend payout ratio used as the main explanatory variable. The controlling variables were firm size, tangibility and leverage. The findings of this study indicated that there is positive and significant relationship between profitability and dividend pay-out policy decision of Ethiopian private insurance companies. This result is also consistent with the Bird-in -the hand theory. The result also shows that leverage, size of insurance company and tangibility has relationship with profitability of insurance companies.
\end{abstract}

Keywords: Profitability, Dividend Payout, Private Insurance Companies, Ethiopia

\section{Introduction}

Since the last eight years, Ethiopia has continued to maintain the double digit growth. The vigorous and broad based economic growth places Ethiopia among the top performing African and other developing Asian countries [21]. In the rapidly growing economies of Ethiopia, as in many other emerging markets, the insurance companies are expected to play a crucial role. The survival of any firm is dependent on the continuous investment in facilities and the employment of internal financing, through the use of retained earnings from an integral part of the sources of finance to fulfill the investment needs.

Dividend policy has attracted great interest of finance scholars over the past decade and stillit's one of the controversial issues in field of finance. Dividend refers to a distribution of earnings to the shareholders of a company that are usually declared by the board of directors and paid to shareholders of record. Generally, the main purpose of investors when investing their assets is to search for income or the rate of returndistribution of earnings in the form of dividend is one of the basic decisions in areas of finance. Companies view the dividend decision as critical because it defines what funds flow to investors and what funds are retained by the firm for investment [23]. Dividend policy can also provide information to stakeholders concerning the company's performance. There are two schools of thoughts on the relationship between dividend policy and the firm performance. In perfect capital market dividend policy has no impact on the value of firm [18]. But other researchers opposed this dividend irrelevance theory and stated that a large number of factors determine capital market to be imperfect and perfect market is almost impractical in most case. In most cases the following factors such as taxes, 
agency cost, and transaction cost exist [12].

Though, a lot of research in this area has been conducted they found mixed result. Dividendtheory is among the top 10 unsolved issues in corporate finance [10]. Dividend policy determines financing and investing decisions of firm. When cash dividend is distributed among shareholders, it affects the liquidity of firm. Dividend payments decreases retained earnings for investments and increase the need for external financing. So, it influences capital structure, cost of capital of firm and ultimately the profitability of the firm. Dividend pay-out also positively impacts the value of the stock.

There have been several studies on determinants of dividend payout in Ethiopian Banks and insurance companies such as $[16,19]$. A study conducted on dividend policy and bank performance: the case of Ethiopian private commercial banks [22]. But, as to the researchers' knowledge there is no study conducted on the relationship between dividendpolicy and profitability of private Insurance companies in Ethiopia. Hence, the main objective of this study is to examine the relationship between dividend policy and firm's profitability by taking evidence from Ethiopian companies. Specifically, this research examined the relationship between dividend policy and the profitability of Ethiopian Private insurance companies.

\section{Literature Review}

In this chapter the theories and findings of previous research on dividend policy and profitability and other determinants of profitability are presented respectively.

\subsection{Dividend Irrelevance Theory}

When markets are perfect, dividends are irrelevant to the value of the firm [18]. Therefore, the market value of the firm is not affected whether a company pays dividends or not. Moreover, under perfect market conditions, the companies' performance is independent of dividend [18]. However, this dividend irrelevance theory is opposed by the following authors [3, 7]. They argues that that market imperfections is common reality and should be considered when evaluating corporate dividend payment and firm performance.

\subsection{Bird in the Hand Theory}

According to the bird-in-hand theory declares that the future cash flows are uncertain, hence, investors prefer dividend than retained earnings and future capital gain. Due to this reason, higher dividend payout ratio will results in increase the value of the firm [14]. In other words, investors prefer current dividend and those high payout firms will be preferred by most investors and ultimately the stock price will increase.

\subsection{Signaling Theory}

As per this theory, dividend are irrelevance for firm value, they also stated that in the real world disregarding the perfect capital markets, dividend provides an "information content" which may affect the market price of the stock [18]. Many researchers have thereafter been supporting the signaling theory and today it is seen as one of the most influential dividend theories. One of the most acknowledged studies regarding signaling theories which states that dividends may function as a signal of expected future cash flows [8]. Under these circumstances even though there is a tax disadvantage for dividends, companies would choose to pay dividends in order to send positive signals to shareholders and outside potentialinvestors [8].

\subsection{Tax Preference Theory}

The tax preference theory asserts that low dividend ratios lower the required rate of return and increase the market value of firm's stock. The M\&M assumptions of a perfect capital market exclude any possible tax effect. It has been assumed that there is no difference in tax treatment between dividends and capital gains. However, in the real world taxes exist and may have significant influence on dividend policy and the value of the firm. In general, there is often different tax treatment between dividends and capital gains in different countries, and, because most investors are interested in aftertax return, the influence of taxes might affect their demand for dividends. The tax-effect hypothesis suggests that low dividend payout ratios lower the cost of capital and increase the stock price. This argument is based on the assumption that dividends are taxed at higher rates than capital gains. In addition, dividends are taxed immediately, whiletaxes on capital gains are deferred until the stock is actually sold [23].

\subsection{Clientele Effect Theory}

This theory is also another theory related to dividend policy. The theory identifies that different groups /clientele of investors prefer different dividend payment policies. Some investors may want the high payout firms and others may prefer and low payout firms and future investment and getting capital gain as a result of expansion. If dividend income is taxed at a higher rate than capital gains, investors in high tax bracket may prefer no dividend or low-dividend paying stocks. On the other hand, an investor in a low tax bracket would definitely invest in stocks with higher returns as he currently does not have a large tax liability [23].

\subsection{Agency Theory}

Agency theory is one of the most influential theories. A firm's dividend policy may reduce agency problems between managers and shareholders and, in turn, enhance the firm's value to shareholders [10]. Dividends are a way to solve agency problems where managers can use excess free cash flows to pursue their own interests. By paying dividends to shareholders, free cash flows are reduced and thus managers have no opportunity to make suboptimal investments on less value adding investments [13]. 


\subsection{Previous Empirical Studies}

The relationship between the dividend policy and firm's financial performance conducted on the Ghana Stock exchange listed firms and the findings indicated that dividend policy is significant and positively related to the firm's performance [7]. Another study also found that dividend payout affects firm performance positively and significantly [20]. The empirical study recommended that, dividend policy does have a significant impact on return and that the higher the dividends paid the lower is the return [12]. Therefore, these show that dividend policy is relevant and therefore affects the performance of a firm hence its value contrary to theories that view dividend policy as irrelevant. Companies with more generous dividend policy are likely to attract more investors and this would help improve their performance. The company would be performing well because of availability of funds through primary issue of equity shares and the shares would be actively traded on the stock exchange and improving the company performance in the market [27]. Dividend policies convey information to the depositors as well as to the shareholders, assisting them in uncovering the actual financial conditions of the bank [6].

The determinants of dividend payout conducted in the Nigerian banking industry over the period 2006 to 2008 [24]. The study employed pooled regression techniques using the data of the Nigerian quoted banks. The study result showed that profitability, Liquidity, Size and Activity mix are statistically significant factors which positively influenced dividend payout. The results also show that revenue growth, debt-equity ratio, retained earnings, loan deposit ratio and loan loss provision negatively influence dividend policy.

\subsection{Control Variables and Performance}

This study used the following control variables that would influence performance include size, leverage, tangibility. Several empirical studies have shown that firm size influences firm's financial performance. Larger firms have more resources and capacities and achieve economies of scale and are more diversified investment area that small firms [1]. Moreover, large firms can get economies of scale advantage and more efficient compared to small firms. Besides, small firms may have capability than large firms; henceforth they may find it difficult to compete with the large firms particularly in highly competitive markets [5]. Firm size has a significant impact on financial performance of insurance companies and this finding is consistent with prior studiesthatindicated that the larger firms are more profitable compared with small firms $[17,11]$. By the same token, large firms have more resources, more infrastructure facilities and management expertise that result in high performance.

With regard to leverage, the relationship between short term debt and/or long term debt and the performance of firms. A short-term debt has a significant positive relationship with the performance of firms suggesting that short-term debt tends to be less expensive; and therefore incremental short-term debt in capital structure tends to lead to an increase in performance levels of firms. Similarly, the study also revealed that while shareholders' fund (i.e. equity shareholders) has a significant positive impact on the performance of firms; on the other hand, it was observed that long term debt has a significant negative impact on the performance of firms since it is relatively more expensive due to certain direct and indirect costs associated with it [28]. It was found a positive and significant relationship between short term debt to total asset and return on equity [1]. However, there is statistically insignificant relationship for short term debt to total asset with return on equity in the emerging market economies [9].

With regard to leverage, the pecking order theory indicates a negative relationship between debt ratio and firm financial performance. Though, the agency theory suggests that higher leverage is expected to reduce agency costs between managers and shareholders, reduce inefficiency and thereby lead to improvement in firm's performance. Thus, it is expected that there is a positive relationship between debt ratio and performance measure [26].

\section{Research Methodology}

The main aim of this study is to examine the relationship between dividend policy and private insurance company's profitability in Ethiopia. This study employed explanatory research design and used to explain the relationship between dividend payout policy and insurance company's profitability. To achieve its objective, this study used a panel data and pooled OLS estimator model. Panel data gives more informative data, more variability, less collinearly among variables, more degree of freedom and more efficiency [15].

The study used secondary source of data and the secondary sources of data were collected from National Bank of Ethiopia and the websites of each insurance companies. As the national bank of Ethiopia 2015 annual report shows Ethiopia has a total of 17 insurance companies. The data were collected from 8 private insurance companies out of 17 for the period of 2006 to 2015 . To be included in the sample they were expected to have insurance business experience of at least five years financial reports and only private insurance companies were included in the sample.

\section{Method of Data Analysis}

The main objective of this study was to examine the relationship between dividend payout decision and firm's profitability. This study was conducted using 8 insurance companies' data for the period of 2006-2015. It has a total of 80 observations. In this study STATA software version 10 is used for estimating regression parameters. Hausman test has been employed to choose between random effect and fixed effect models.

To decide which model is most appropriate, the Hausman specification test was employed for regression model of the study to select between random and fixed effects. 
Based on the Hausman specification test, the random effects model was preferred to the fixed effect model. Then after chosen the random effect model further test is also made comparing with pooled OLS estimator, finally the result supports the pooled OLS estimator. Thus, the regression parameters in this study are estimated using thePooled OLS regression model. The F-statistics value of 25.99 and $\mathrm{p}$ - value of 0.001 reveal that the model as a whole is fit (See Table 3). In addition, to test the existence or not-existence of multicolliniarity problem, Variable Inflation Factor (VIF) technique is employed. The variance inflation factor, VIF, is a measure of the reciprocal of the complement of the intercorrelation among the predictors. A variable whose VIF values are greater than 10 indicate the possible problem of multicolliniarity [15]. The results of VIF in (Table 3) below indicates there is no VIF score above value of 10 suggesting that there is no perfect co-linearity among independent variables in the model.

Model Specification

The Econometrics model used for this study is similar with the previous study [26]. The research model is written as follows

$$
\text { ROAit }=\beta 0+\beta 1 \text { DVPit }+\beta 2 \text { SIZE it }+\beta 3 \text { TANGit }+\beta 4 \text { LEVit }+ \text { e it }
$$

Where;

$\mathrm{ROA}=$ Return on Asset is measured as the ratio of profit before interest and tax to total assets

$\mathrm{DVP}=$ Dividend payout Policy is measured as the ratio of dividend paid to profit after tax

$\mathrm{SIZE}=$ Company size is measured as the natural logarithm of total assets

$\mathrm{TANG}=$ Tangibility is measured as the ratio of non-current asset to total assets

$\mathrm{LEV}=$ Leverage is measured as the ratio of total debt to total assets

$\beta 0=$ the constant term

$\mathrm{e}=$ error term

\section{Results and Discussion}

Table 1. Descriptive statistics.

\begin{tabular}{llllll}
\hline Variable & N & Mean & Maximum & Minimum & Std. Deviation \\
\hline ROA & 80 & 0810 & 0.6132 & -.0471 & 0.748 \\
DVP & 80 & 7361 & 0.987 & 0.000 & 0.240 \\
SIZE & 80 & 4973 & 7.603 & 0071 & 1.171 \\
TANG & 80 & 1853 & 6545 & 0227 & 112 \\
LEV & 80 & 6307 & 8078 & 4528 & 077 \\
\hline
\end{tabular}

Source, Annual financial reports (2006-2015).

The result on the above table 1 indicated that, dividend payout was measured as total dividend by net income after tax. The mean of dividend payout ratio was 0.74 ( 74 percent) and standard deviation 24 percent. This result shows on average, private insurance share companies in Ethiopia paid 74 percent of their earning as a dividend during the study period of study. Regarding the standard deviation, it means the value of dividend can deviate from its mean to both sides by 24 percent. The maximum and minimum of dividend payout ratio were 0.987 and 0.00 respectively.

With regard to profitability, the average of profitability was 8 percent. In other words, on the average, for each one birr investment in the asset of private insurance share companies there was 0.08 cent return. The maximum value of ROA for the year was 0.61 whereas the minimum value was -0.05 . Also the variation was 0.075 ; it means the value of profitability can deviate from its mean to both sides by 7 percent.

Concerning to leverage, the average of debt ratio of the sampled firms was 63 percent. It discloses that debt represents nearly 63 percent of the capital of private insurance share companies. The highest debt ratio for a company in a particular year was 0.81 and the minimum ratio for a company in a year was 0.453 . The standard deviation was 0.08 ; the result indicated that leverage can deviate from its mean to both sides by 8 percent.

As far as the size of the private insurance companies concerned, the mean of size over the period 2006 up to 2015 was 0.5 and standard deviation for the size variable 1.17 . The size of private insurance company in the industry during the study period ranges from minimum of 0.0071 to maximum of 7.606. The variation in size during the study period indicates that private insurance share company has been growing in size during the study period.

The mean, minimum and maximum value of tangibility variable was $0.185,0.023$ and 0.7 respectively. The standard deviation was 0.112 , the result indicated that tangibility can deviate from its mean to both sides by 11 percent.

Table 2. Pearson Correlation matrix.

\begin{tabular}{lllll}
\hline & ROA & DVP & SIZE & TANG \\
\hline ROA & 1 & & & \\
DVP & $0.080^{*}(0.026)$ & 1 & & \\
SIZE & $0.166^{* * *}(0.001)$ & $0.104^{*}(0.052)$ & 1 & 1 \\
TANG & $-0.005(0.040)$ & $-0.069(0.860)$ & $-0.68^{* * *}(0.002)$ & $-0.060(0.349)$ \\
LEV & $-0.382^{* * *}(0.000)$ & $0.086(0.474)$ & $0.079(0.451)$ & 1 \\
\hline
\end{tabular}

*** and ${ }^{* * *}$ indicate significant at $10 \%, 5 \%$ and $1 \%$ levels respectively. significant- values are in brackets

The results of correlation matrix (Table 2) above indicates that the correlation matrix of the study variables. The result shows that ROA (profitability) is positively associated with
DVP (dividend pay-out) at 5\% significance level. For the controlled variable SIZE, profitability (ROA) was positively correlated with it at $1 \%$ significant level. However, 
profitability (ROA) was negatively correlated with debt ratio (leverage). Though, the relationship between ROA and asset tangibility is negative correlated at $5 \%$ significant level.

Table 3. Regression results.

\begin{tabular}{|c|c|c|c|c|}
\hline \multicolumn{2}{|l|}{ Variable } & \multirow{2}{*}{$\frac{\text { ROA }}{-1.715^{*}}$} & \multirow[t]{2}{*}{ VIF } & \multirow{2}{*}{ P-value } \\
\hline \multicolumn{2}{|l|}{ Constant } & & & \\
\hline \multicolumn{2}{|l|}{ DVP } & $0.801^{* *}$ & \multirow{7}{*}{$\begin{array}{l}1.65 \\
1.55 \\
1.53 \\
1.12\end{array}$} & 0.043 \\
\hline \multicolumn{2}{|l|}{ SIZE } & $3.992^{* * *}$ & & 0.000 \\
\hline \multicolumn{2}{|l|}{ TANG } & $-1.491^{* *}$ & & 0.023 \\
\hline \multicolumn{2}{|l|}{ LEV } & $-1.221^{* * *}$ & & 0.000 \\
\hline Adjusted R2 & 0.652 & & & \multirow{3}{*}{0.001} \\
\hline & $25.99^{* * *}$ & & & \\
\hline Observation & 80 & & & \\
\hline
\end{tabular}

${ }^{*},{ }^{* *}$ and ${ }^{* * *}$ indicate significant at $10 \%, 5 \%$ and $1 \%$ levels respectively, tvalues are in parentheses

In this study the dependent variable is insurance companies profitability measured by ROA and explanatory variables are dividend payout, leverage, tangibility, size of the firm. The adjusted $\mathrm{R}$ square value is $65.2 \%$ and it suggests that $65.2 \%$ of the variation in the dependent variable explained by the variation in the explanatory variables.

The regression results in Table 3 above shows that there is statically significant relationship between dividend payout decision and profitability of private insurance companies at 5 percent level of significance. This shows that when profitability increases by one unit, dividend payout of private insurance share company's increases by 81 percent other factors remain constant. In other words, profitability influences insurance companies to pay dividend to their shareholders during the study period. This result is consistent with the results of previous studies such as $[26,2,25]$. Moreover, the result is consistent with Birdin- the hand theory, which states that investors prefer current dividend than future capital gain. However, insurance companies should sometimes reinvest their earnings just to become more competent in the global arena rather than paying higher dividend to their shareholders when their earning is higher.

The study also shows that there is statistically significant relationship between firm size and profitability. The variable has a positive relationship with insurance company's profitability (ROA) at $1 \%$ significant level. This result shows that the large insurance companies earn more profit than small insurance companies during the study period. This result is consistent with the findings of [26].

The findings of this study also indicated that there is negative and significant relationship between leverage and profitability of insurance companies during the study period at 1 percent significance level. This study shows when insurance companies are use debt as a source of finance, there profitability will decline. This finding is consistent with other research findings $[23,26]$. And it is consistent with the pecking order theory which states that firms prefer internal source of finance before looking for external finance sources. Hence, based on this findingit's recommended that insurance companies should rely on internal source of finance before looking to external sources of finance (debt).

Moreover, the study result shows that there is significant negative relationship between tangibility and profitability (ROA) during the study period. This result shows that insurance companies that have more tangible assets earn lower profit during the study period; this may be due to poor management of assets or inefficient utilization of tangible assets.

\section{Conclusion}

Dividend payout policy decision is one of the core decision in finance and it is all about how much of earning to be paid to investors and how much to retain for future expansion/investment need of the company. Hence, Making of the correct dividend payout decision is valuable both for the company as well as for investors. This study examined the relationship between dividend payout ratio and profitability of Ethiopian private insurance companies for the period of 2006-2015.

Return on Asset (ROA) is used as a measurement of profitability of insurance companies and dividend payout ratioproxied for dividend payout policy decision. The findings of the study indicated that there is positive and significant relationship between profitability (ROA) of insurance companies and their dividend payout decision (DVP) during the study period. The results of this study also revealed that firm size and profitability have positively and significantly correlated with profitability. In addition, leverage (LEV) and tangibility (TANG) has negative and significant relationship with profitability (ROA). Hence, profitability of insurance companies is one of the major factors that affect the dividend pay-out policy decision of the private insurance companies during the study period.

\section{References}

[1] Abor, J. (2005), "The effect of capital structure on profitability: an empirical analysis of listed firms inGhana", Journal of Risk Finance, Vol. 6, pp. 438-47.

[2] Adediran, S. A and Alade, S. O (2013). Dividend policy and corporate performance in Nigeria. AmericanJournal of Social and Management Sciences, 4 (2), 71-77.

[3] Allen F. and Michaely, R. (2002). "Payout policy, Center for Financial Institutions", Working Papers.

[4] Allen, F and Michaely, R (2005). Payout policy. Centre for Financial Institutions, Working Papers.

[5] Almajali, A. Y., Alamro, A. S. and Al-Soub, Y. Z. (2012). Factors Affecting the FinancialPerformance of Jordanian Insurance Companies Listed at Amman Stock Exchange. Journal ofManagementResearch, ISSN 1941-899X, Vol. 4, No. 2.

[6] Ameer, R. (2007). "Product market competition regulation and dividend payout policy of Malaysianbanks", Munich Personal Repec. Achieves (MPRA), Aston University. 
[7] Amidu, M. (2007). "How does Dividend Policy affect Performance of the Firm on Ghana StockExchange?", Investment Management and financial Innovations 4 (2), 103112.

[8] Bhattacharya, S. (1979). "Imperfect Information, Dividend Policy, and 'The Bird in the HandFallacy", Bell Journal of Economics, 10 (1), 259-270.

[9] Bokpin and Areko (2009); Ownership structure, corporate governance and capital structure decisionsof firms: Empirical evidence from Ghana: Studies in Economics and Finance 26 (October); 246-256.

[10] Brealey, R. A., Myers, S. C., \& Allen, F. (2008). Principles of Corporate Finance. 9 Ed. New York.

[11] Chen, R. andWong, K. A. (2004). The Determinants of Financial Health of Asian InsuranceCompanies. The Journal of Risk and Insurance, 71 (3), 469-499.

[12] Collins and McKeown (1979); The role of insiders and dividend policy; A comparison study ofregulated unregulated firms: Journal of financial and strategic decisionsvol 9 No 2 .

[13] DeAngelo, H., DeAngelo, L., and Stulz, R. (2006). "Dividend Policy and the earned/contributedcapital mix: a test of the lifecycle theory", Journal of Financial Economics, 81, 227-254.

[14] Gordon, M. J. (1963). "Optimal Investment and Financing Policy", The Journal of Finance, 18 (2), 264-272.

[15] Gujarati, N (2004), Basic Econometrics, McGraw-Hill Book Company, Singapore.

[16] Kinfe, T. (2011). Determinants of dividend payout: an empirical study on banking industry inEthiopia, 2006-2010, Master thesis, Addis Ababa University.

[17] Liargovas and Skandalis (2008). Capital Structure and Corporate Performance in MalaysianConstructionSector. International Journal of Humanities and Social Sciences. 1 (2); 28-36.

[18] Miller, M. H. and Modigliani, F. (1961), "Dividend policy, growth, and the valuation of shares", Journalof Business, 34, 411-433.
[19] Mulualem, A. (2017). Determinants of dividend payout: a case studyof private insurance share companiesin Ethiopia: Master thesis, Addis Ababa University.

[20] Murekefu, T. M and Ouma, O. P (2013). The relationship between dividend payout and firm performance: astudy of listed companies in Kenya. European Scientific Journal, 8 (9), 199-202.

[21] National Bank of Ethiopia (2015). Annual report of national bank of Ethiopia. Retrieved fromhttp://www.nbe.gov.et

[22] Nebyu and Tilahun, (2013). Dividend policy and bank performance: the case of Ethiopianprivate commercial banks: international journal of research in commerce, it \& management.

[23] Ross, S. A., Westerfield, R. W. \& Jaffe, J. (2008). Corporate finance, alternate edition, McGraw Hill.

[24] Rufus. A\&Soyoye. M (2014); Determinants of Dividend Payout in the Nigerian Banking Industry: Proceedings of 9th Annual London Business Research Conference 4 - 5 August 2014, ImperialCollege, London, UK, ISBN: 978-1-922069$56-6$.

[25] Salehnzhad, S. H (2013). A study of relationship between firm performance and dividend policy byfuzzy regression: International Journal of Accounting and Financial Reporting, 3 (2), 70-75.

[26] Sunday, Ademola and Oyefemi, (2015). Dividend pay-out policy and firm financial performance: evidencefrom Nigerianlisted non-financial firms.

[27] Tornyeva, K., andWereko, T., (2012), "Corporate Governance and Firm Performance: Evidence fromthe Insurance Sector of Ghana", European Journal of Business and Management, Vol 4, No. 13.

[28] Uwalomwa and Uadiale (2012); Dividend Policy and Firm Performance: A Study of Listed Firms inNigeria: Journal of Accounting and Management Information systems 2012, vol. 11 , issue 3, 442-454. 